\title{
Plasma Membrane Calcium ATPases as Novel Candidates for Therapeutic Agent Development
}

\author{
Emanuel E. Strehler \\ Department of Biochemistry and Molecular Biology, Mayo Clinic College of Medicine, Rochester, MN, USA.
}

Received, May 9; Revised, May 9; Accepted, May 10; Published, May 10, 2013.

\begin{abstract}
Plasma membrane $\mathrm{Ca}^{2+}$ ATPases (PMCAs) are highly regulated transporters responsible for $\mathrm{Ca}^{2+}$ extrusion from all eukaryotic cells. Different PMCA isoforms are implicated in various tasks of $\mathrm{Ca}^{2+}$ regulation including bulk $\mathrm{Ca}^{2+}$ transport and localized $\mathrm{Ca}^{2+}$ signaling in specific membrane microdomains. Accumulating evidence shows that loss, mutation or inappropriate expression of different PMCAs is associated with pathologies ranging from hypertension, low bone density and male infertility to hearing loss and cerebellar ataxia. Compared to $\mathrm{Ca}^{2+}$ influx channels, PMCAs have lagged far behind as targets for drug development, mainly due to the lack of detailed understanding of their structure and specific function. This is rapidly changing thanks to integrated efforts combining biochemical, structural, cellular and physiological studies suggesting that selective modulation of PMCA isoforms may be of therapeutic value in the management of different and complex diseases. Both structurally informed rational design and high-throughput small molecule library screenings are promising strategies that are expected to lead to specific and isoform-selective modulators of PMCA function. This short review will provide an overview of the diverse roles played by PMCA isoforms in different cells and tissues and their emerging involvement in pathophysiological processes, summarize recent progress in obtaining structural information on the PMCAs, and discuss current and future strategies to develop specific PMCA inhibitors and activators for potential therapeutic applications.
\end{abstract}

This article is open to POST-PUBLICATION REVIEW. Registered readers (see "For Readers") may comment by clicking on ABSTRACT on the issue's contents page.

\section{INTRODUCTION}

The plasma membrane calcium ATPases (PMCAs) are members of the large family of P-type ion pumps characterized by the formation of a phosphorylated intermediate (hence their name) during the reaction cycle [1]. P-type ion pumps are integral membrane proteins found in the plasmalemma or organellar membrane of all cells, where they are responsible for the generation and maintenance of steep ion gradients (e.g., $\mathrm{Ca}^{2+}$, $\mathrm{Na}^{+} / \mathrm{K}^{+}$or $\mathrm{H}^{+}$pumps) or the removal of toxic heavy metal ions (e.g., $\mathrm{Cd}^{2+}, \mathrm{Co}^{2+}, \mathrm{Pb}^{2+}, \mathrm{Zn}^{2+}$ ), among other functions $[2,3]$. The PMCAs belong to the type IIB subfamily [4] or family 2 [5] (see www.tcdb.org) of P-type ATPases and represent the main high-affinity system responsible for the expulsion of $\mathrm{Ca}^{2+}$ across the cell membrane. Mammalian PMCA isoforms 1-4 are encoded by separate genes on chromosomes 12q21.3, 3p25.3, $\mathrm{Xq} 28$, and 1q32.1 in humans, and on chromosomes 10C3, 6E3, XA7.3, and 1E4 in mice, respectively. Each of the PMCA genes (human genome database nomenclature ATP2B1-ATP2B4) shows a complex intron-exon structure including multiple alternatively spliced exons. Alternative RNA splicing at two main "hotspots" referred to as sites $\mathrm{A}$ and $\mathrm{C}$ leads to the production of multiple splice variants for each PMCA isoform [6]. Over 30 different PMCA splice forms can thus be generated in mammalian organisms. A schematic overview of the main splice options and the nomenclature for labeling the PMCA splice variants is given in Figure 1.

PMCAs are single polypeptides of about 1,100 to 1,250 amino acid residues with a molecular mass of 125 to $140 \mathrm{kDa}$. They contain 10 membranespanning segments and their $\mathrm{N}$ - and C-termini are both on the cytosolic side, as is the bulk of their mass including the two major intracellular loops making up most of the A (actuator) and N/P (nucleotide-binding/catalytic phosphorylation)

Corresponding Author: Emanuel E. Strehler, Department of Biochemistry and Molecular Biology, Mayo Clinic College of Medicine, 200 First Street S.W., Rochester, MN, USA; Email: strehler.emanuel@mayo.edu 
domains [7]. In animal PMCAs, the C-terminal tail is crucial for pump regulation: it contains the autoinhibitory sequence that interacts with the major cytosolic loops to keep the PMCA in a relatively inactive state at low $\left[\mathrm{Ca}^{2+}\right]_{i}$, as well as the calmodulin-binding domain (which partially overlaps with the auto-inhibitory domain) and sites of regulatory phosphorylation and protein-protein interactions [7-11]. A generic scheme of the PMCA illustrating its main domain architecture is shown in the top panel of Figure 1.

The importance of the PMCA for the maintenance of intracellular $\mathrm{Ca}^{2+}$ homeostasis was recognized soon after the existence of such a dedicated system for expelling $\mathrm{Ca}^{2+}$ against a large concentration gradient had been demonstrated [12, 13]. However, because the function of the PMCA was thought to be essentially that of a generic "sump pump" responsible for restoring and maintaining the low global resting $\left[\mathrm{Ca}^{2+}\right]_{\mathrm{i}}$ level following a temporary increase, there was only modest interest in pursuing the PMCA as a drug target in the absence of more specific information on tissue expression and functional specialization. As will be discussed below, formidable additional challenges have also hampered earlier attempts to develop PMCA modulators. On the other hand, the advent of molecular cloning, whole-genome and transcriptome sequencing revealed the presence of a large family of different PMCA isoforms, and work over the past 10-15 years has shown that many PMCAs fulfill specialized roles and are expressed in cells and tissues in a spatially and temporally restricted manner. Together with rapidly emerging evidence that these pumps play diverse roles in different diseases, these recent developments have dramatically increased the interest in targeting the PMCAs for therapeutic agent development.

\section{PMCA DIVERSITY SUGGESTS FUNCTIONAL SPECIALIZATION}

The presence of a large family of PMCA isoforms and splice variants immediately begs the question of the functional significance of this diversity. Attempts to address this question have included determining the expression pattern of the PMCAs during development and in different organs and tissues, studying their subcellular localization in specialized cell types, and their co-localization with proteins that may be functionally connected. In parallel, biochemical studies on isolated PMCAs either purified from a suitable tissue source (mainly human erythrocyte ghosts) or expressed as recombinant protein have been instrumental in determining enzymatic, regulatory, and structural differences among isoforms and splice variants. Combined with in vitro mutagenesis studies, $\mathrm{Ca}^{2+}$ signaling assays in cultured cells, and physiological experiments on tissues and in animal models, these approaches have clearly shown that PMCA isoforms and splice variants perform very different functions ranging from vectorial transport of bulk $\mathrm{Ca}^{2+}$ to fine-tuning local $\mathrm{Ca}^{2+}$ signaling events in localized membrane microdomains.

\section{Evidence from Expression and Localization}

Studies at the mRNA and the protein level indicate that PMCA1 is ubiquitously expressed in all tissues [14-17] and can be detected by in situ hybridization from the earliest time points $(9.5 \mathrm{dpc})$ in mouse embryonic development [18]. Consequently, PMCA1 has been referred to as a "housekeeping" PMCA, although this terminology is misleading and should be abandoned in the face of evidence showing that different PMCA1 splice variants are uniquely expressed in defined cell types (e.g., fast muscles and specific neurons) where they probably perform specialized functions $[15,16,19-23]$. PMCA4 is similarly detected in most adult tissues although it appears later in mouse development (around $12.5 \mathrm{dpc}$ ) and at much lower levels [18]. $\mathrm{PMCA} 4 \mathrm{x} / \mathrm{b}$ is the major pump isoform found in human erythrocytes, whereas PMCA4z/a and 4x/a are relatively abundant in the heart and smooth muscles [24]. In contrast to PMCA1 and PMCA4, PMCA2 and PMCA3 show a much more restricted tissue distribution, with abundant expression in specific areas of the brain and in skeletal muscle [24]. The full complexity of PMCA isoform expression becomes evident when the dynamic patterns of splice variant distribution are taken into account. Thus, even within the same tissue or cell type, multiple PMCAs are frequently expressed simultaneously, but at different levels and with distinct subcellular localization. This is especially notable in highly polarized cells such as in retinal photoreceptor cells where PMCA1b is present on the inner segment and synaptic terminal membrane and PMCA4b is restricted to the synaptic terminals [25], or in cochlear hair cells where PMCA2w/a is exclusively present on the apical stereocilia and PMCA1x/b on the basolateral membrane [26]. 

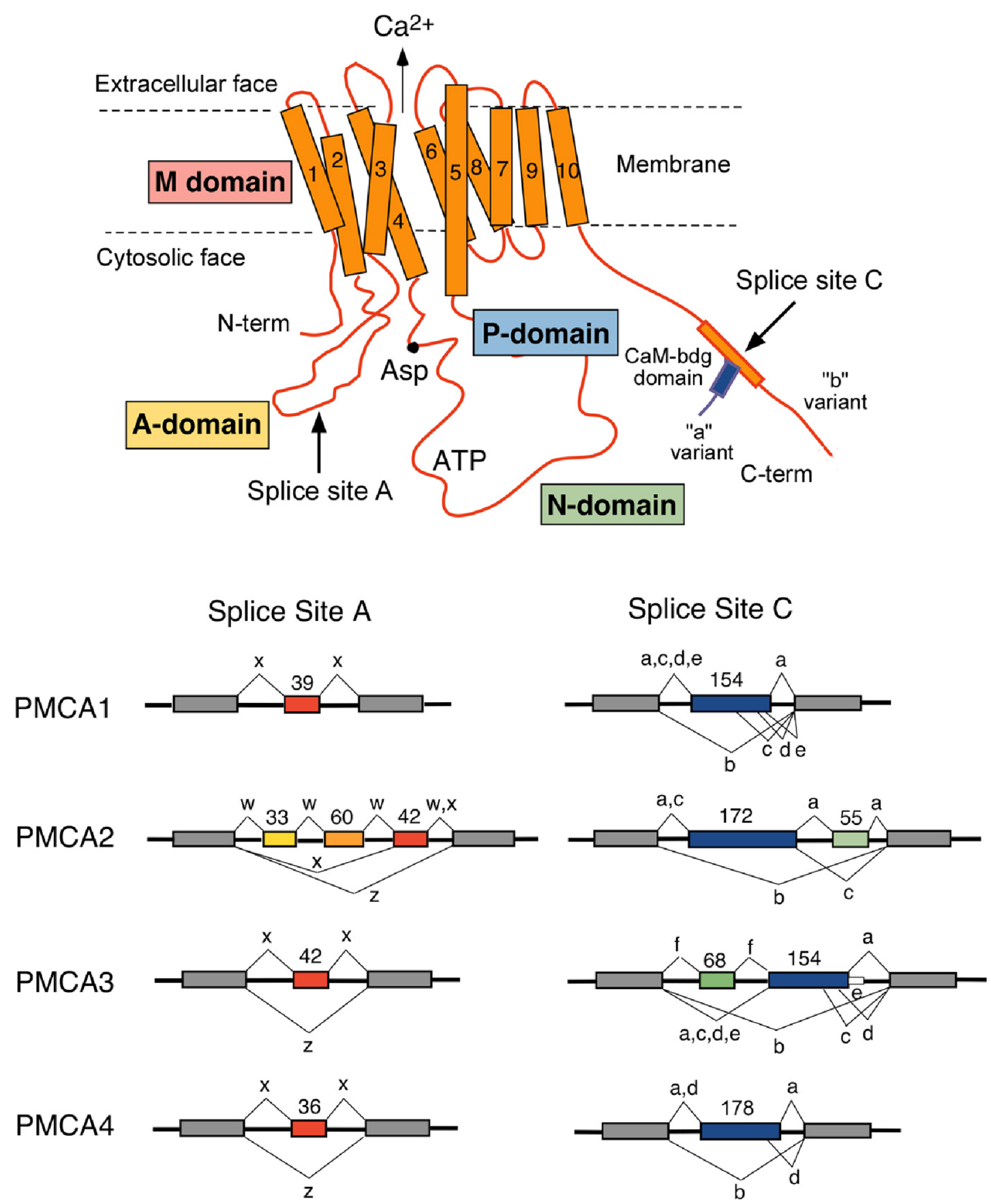

Figure 1. Scheme of the PMCA (top) and of the alternative splice options generated from the 4 mammalian PMCA genes (bottom). The major domain organization of the PMCA is shown in the scheme on top. The ten membrane-spanning regions are numbered and shown as cylinders forming the $\mathrm{M}$ domain. The amino- $(\mathrm{N}$-term) and carboxy-terminal ends $(\mathrm{C}-$ term), the conserved aspartate (Asp) residue undergoing phosphorylation during the reaction cycle, and the ATP binding site (ATP) are labeled. The direction of $\mathrm{Ca}^{2+}$ transport is indicated by an arrow. The three main cytosolic domains are labeled A (actuator), P (phosphorylation), and N (nucleotide-binding). Splice sites A and C are indicated by arrows. Splicing at site $\mathrm{C}$ affects the calmodulin-binding (CaM-bdg) domain and results in major splice variants "a" and "b", which differ in their C-terminal amino acid sequence due to a shift in reading frame (indicated as separate lines). Bottom: Exon structure of the regions involved in alternative splicing in the four human PMCA genes. Constitutively spliced exons are shown as gray boxes. The sizes of alternatively spliced exons (colored) are given in nucleotides, the alternative splicing options are indicated by connecting lines, and the resulting splice products are labeled by their lowercase symbol. Combinatorial use of the splice options at sites $A$ and $C$ yields over 30 possible PMCA splice variants. 
It is therefore not surprising that the lack or altered activity of specific PMCAs results in very different phenotypes and pathological outcomes, supporting the notion of functional specialization of these pumps.

\section{Evidence from Interacting Proteins}

Evidence for the functional differentiation among PMCAs has also come from molecular, biochemical, and cellular studies that have identified a growing number of proteins that specifically interact with one or several PMCA isoforms or splice forms. The binding of calmodulin as the major regulator of the PMCAs has already been mentioned. Although all PMCAs can bind calmodulin, different isoforms and the C-terminal splice variants "a" and " $b$ " of each isoform differ significantly in their affinity for calmodulin and more importantly, in the kinetics of activation/inactivation by calmodulin [27-30]. Yeast two-hybrid and other protein interaction search strategies have uncovered a surprisingly large and diverse number of proteins that interact with different domains of the pumps [24, 31, 32]. A schematic summary of these interactions is shown in Figure 2. The C-terminal sequence of the b- (and most c- and d-) splice variants of all PMCAs conforms to the consensus binding sequence for PDZ domain-containing proteins. Accordingly, many PDZ proteins have been shown to interact promiscuously with multiple PMCA isoforms or more selectively with specific PMCAs via their Cterminal tail. These include membrane-associated guanylate kinase (MAGUK) family members such as PSD95, SAP97, and CASK [33-35] as well as diverse scaffolding, signaling and regulatory proteins including CLP36, NOS-1, Homer, NHERF and PISP/AIPP1, among others [36-40]. Additional proteins were shown to bind to the N-terminal tail $(14-3-3 \varepsilon ;$ [41]) or distinct regions of the intracellular loops of some PMCAs (RASSF-1, calcineurin A, $\alpha 1$-syntrophin) [42-44].

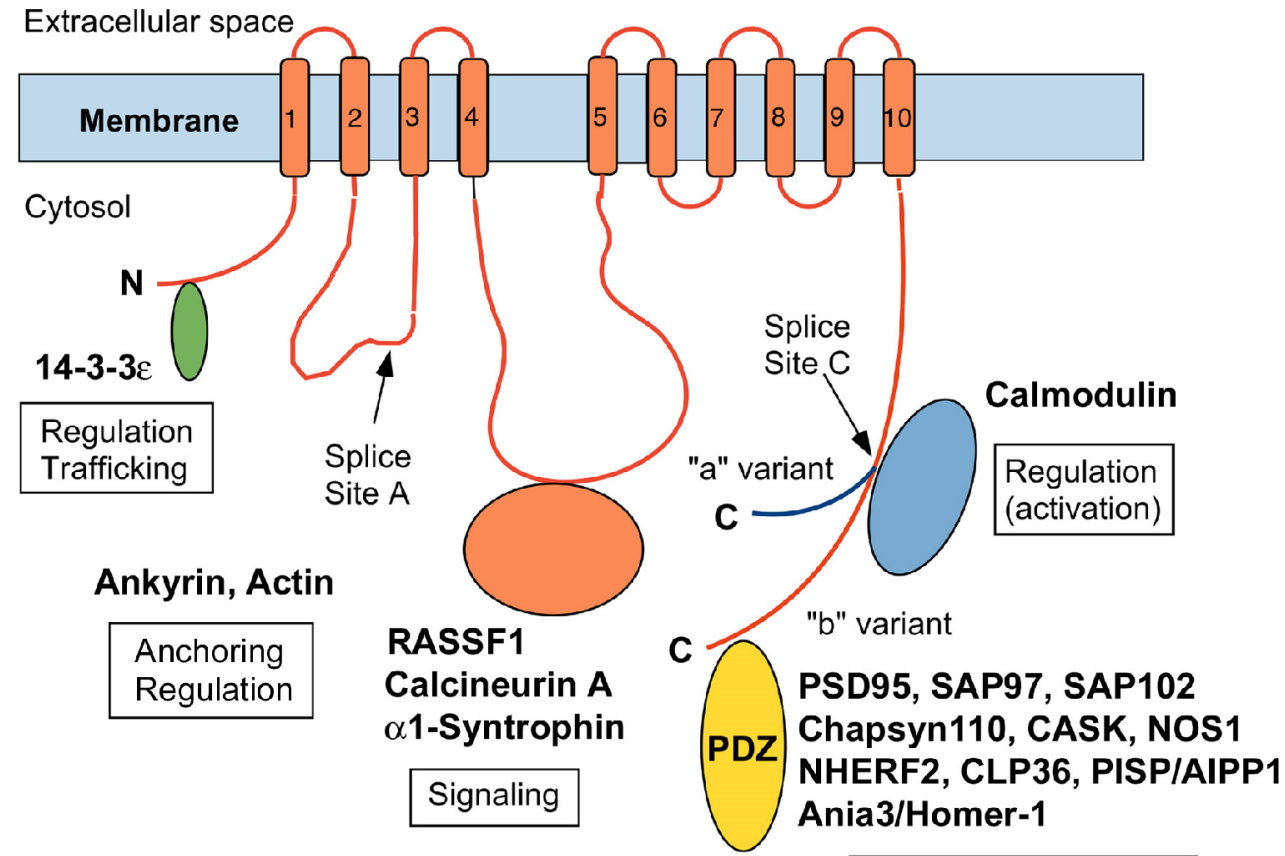

Signaling, Trafficking,

Targeting, Anchoring

Figure 2. Interacting protein partners of the PMCAs and their roles in PMCA regulation and function. PMCA-binding proteins are schematically shown as colored ovals near the domain of the PMCA where they interact. Known or suspected roles of these proteins in PMCA function, regulation, and signaling are indicated in boxes beneath the listed proteins. The two major sites of alternative splicing are also indicated, and the main C-terminal splice variants "a" and "b" are shown with separate C-tails to indicate their sequence divergence. Note that PDZ domain-containing proteins (PDZ) only bind to "b-splice" variants of the PMCA, and that not all PMCA isoforms interact with all of the listed proteins. Ankyrin and actin also interact with the PMCA although the site of interaction has not yet been established. 
Interactions with these proteins serve to target PMCAs to distinct membrane domains, recruit them into multi-protein signaling complexes or to modulate their activity and regulation $[11,32,45-$ 48]. These dynamic protein-protein interactions further augment the functional diversity of different PMCA isoforms.

\section{Evidence from In Vitro Biochemical Studies}

Early biochemical studies on the enzymatic, regulatory and $\mathrm{Ca}^{2+}$ transport properties of the PMCA were performed on material isolated from human erythrocytes [49-52], which was found to correspond mainly to isoform PMCA4b [53]. The advent of molecular cloning and expression of recombinant proteins in different eukaryotic systems allowed subsequent studies on specific PMCA isoforms and splice variants overexpressed in mammalian cells (COS, CHO) as well as in the baculovirus insect cell and in yeast expression systems [28, 30, 54-57]. These studies unequivocally showed that PMCA isoforms differ significantly in their basal $\mathrm{Ca}^{2+}$ ATPase activity, apparent $\mathrm{Ca}^{2+}$ affinity and regulation by $\mathrm{Ca}^{2+} /$ calmodulin, activation or inhibition by protein kinase $\mathrm{C}$, and phosphorylation by other kinases (e.g., PKA, tyrosine kinase src) [24]. This is also true for the major C-terminal alternative splice variants ( $a$ and $b$ ) of the same PMCA isoform, a finding that is not surprising given that the splice directly affects the calmodulin-binding domain (see Fig. 2). Perhaps most significantly, detailed kinetics studies showed that a major distinctive feature of different isoforms and C-terminal splice variants (at least of PMCA2a and 2b, PMCA4a and 4b) concerns their calmodulin association and dissociation rates, which in turn determines the timing of their activation and inactivation [27, 29, $58,59]$. This feature is largely responsible for the finding that there are "fast" and "slow" PMCA isoforms and for what has been called the "memory effect" of the PMCAs, i.e., the concept that PMCAs with slow off-rates for calmodulin dissociation react more rapidly to successive $\mathrm{Ca}^{2+}$ spikes after an initial $\mathrm{Ca}^{2+}$ transient due to calmodulin that remains bound to the pump during the intermittent decrease in $\left[\mathrm{Ca}^{2+}\right]_{\mathrm{i}}[28,58]$. Different PMCAs thus have different "memories" for past activation, resulting in significant differences in how they handle different $\mathrm{Ca}^{2+}$ loads.

\section{Evidence from Calcium Signaling Studies}

To show that PMCA isoforms differ in how they handle intracellular $\mathrm{Ca}^{2+}$ loads, $\mathrm{Ca}^{2+}$ imaging studies have been performed in intact cells (over-) expressing specific PMCAs. Most studies have either used global $\mathrm{Ca}^{2+}$ imaging with (ratiometric) fluorescent $\mathrm{Ca}^{2+}$ indicators (e.g., Fura-2) or global or organelle-specific imaging using the aequorin/coelenterazine luminescence system. This work demonstrated differences between PMCA isoforms in their efficiency of returning single evoked $\mathrm{Ca}^{2+}$ spikes of similar amplitude back to the resting level, as indicated by characteristically different $t_{1 / 2}$ values (half-times of the decay of a given $\mathrm{Ca}^{2+}$ spike). In addition, PMCA isoforms also showed different capacity to reduce the amplitude of $\mathrm{Ca}^{2+}$ signals elicited by IP3-mediated release from the endoplasmic reticulum $[60,61]$. In a more recent study, the genetically engineered $\mathrm{Ca}^{2+}$ sensor GCaMP2 was used to demonstrate the very different, isoform-specific capacity of PMCA2 and PMCA4 in handling ATP-induced $\mathrm{Ca}^{2+}$ loads in MDCK cells [62]. Evidence for isoform-specific function in vivo has also come from studies in which different PMCAs have been selectively down-regulated by RNA knock-down strategies. In an interesting recent study in MDA-MB-231 breast cancer cells, which express both PMCA1b and $4 \mathrm{~b}$, Curry et al. found that silencing of PMCA1 resulted in a very different cellular response to ATP-evoked $\mathrm{Ca}^{2+}$ signals than silencing of PMCA4, and that the outcome on cell survival and apoptosis was also distinct [63]. Although the above studies represent only a small fraction of the many reports that have investigated the role of different PMCAs in cellular $\mathrm{Ca}^{2+}$ handling, they serve to illustrate the nonequivalence of the PMCA isoforms and their functional specialization to fulfill different tasks in cell regulation. This, in turn, suggests that targeting specific PMCAs holds promise in manipulating distinct cellular signaling pathways for potential therapeutic benefit.

\section{PMCA INVOLVEMENT IN DISEASE}

\section{Genetic Evidence from Mutations, Gene} Deletion, and Genome-wide Association Studies

The most compelling evidence for the functional specificity of different PMCAs stems from both natural gene mutations and targeted gene manipulations. Targeted deletion of PMCA1, 2, and 4 (Atp2b1, Atp2b2, Atp2b3) in mice showed vastly 
different phenotypes with homozygous loss of PMCA1 being embryonic lethal, whereas loss of PMCA2 results in deafness, imbalance and ataxia, and loss of PMCA4 results in male infertility with otherwise few overt consequences [64-67]. The early embryonic lethality of PMCA1 knockout mice during the pre-implantation stage supports the essential role of this ubiquitous isoform. While this is not surprising, the phenotypes of Atp2b1+/heterozygotes are perhaps more interesting; studies in these animals showed an important contribution of PMCA1 to (bladder) smooth muscle contractility and cellular susceptibility to apoptosis $[65,68,69]$. From a human disease standpoint, the most exciting recent developments concern findings showing a causal link between PMCA1 genetic variants and hypertension and cardiovascular disease risk [70, 71]. Studying mice with vascular smooth muscle cell-specific Atp2b1 deletion, Kobayashi and coworkers found that PMCA1 knockout resulted in elevated basal $\left[\mathrm{Ca}^{2+}\right]$ as well as increased phenylephrine-stimulated $\left[\mathrm{Ca}^{2+}\right]$ in cultured vascular smooth muscle cells [72]. Importantly, phenylephrine-induced vasoconstriction in arterial rings was higher in the absence of PMCA1, and these mice exhibited elevated systolic blood pressure under resting conditions. Reduced PMCA1 expression and function in the vasculature are therefore a risk factor for hypertension.

The importance of PMCA2 in hearing and balance is obvious from the severe phenotype of engineered Atp2b2-/- mice [64] as well as from numerous spontaneous or chemically induced Atp2b2 mutants whose names (deafwaddler, wriggle, joggle, oblivion, etc.) reflect some of the most notable deficiencies in the affected animals [73-76] (for review, see [77]). The expression, proper targeting (e.g., to the stereocilia of cochlear outer hair cells) and function of PMCA2 are essential for hearing as well as other specific physiological processes such as calcium transport into milk [78], motor neuron coordination and cerebellar synaptic plasticity [79-82]. Specific missense mutations in the ATP2B2 gene have also been identified in at least two separate human pedigrees with congenital sensorineural hearing loss, providing unequivocal evidence for the involvement of this PMCA isoform in specific disease pathology [77, 83, 84].

Evidence for the involvement of PMCA3 in disease is currently sparse. However, exome sequencing recently revealed a missense mutation in the ATP2B3 gene of a human family afflicted with congenital X-linked cerebellar ataxia [85]. As mentioned earlier, PMCA3 is expressed in a highly tissue-specific manner mainly in excitable cells, including at cerebellar parallel fiber-Purkinje neuron synapses $[23,86]$. Thus, deficiencies in PMCA3 function may well underlie or contribute to a variety of neuronal communication disorders.

The male infertility of Atp2b4 (PMCA4) knockout mice has already been mentioned. Proper function of the PMCA4 isoform is essential for dynamic $\mathrm{Ca}^{2+}$ handling to allow hyperactivated sperm motility $[65,66]$. Although it is not yet clear if PMCA4 is the major PMCA isoform in human sperm, targeting the PMCA with specific inhibitors has already been proposed as a potential male contraceptive strategy [87]. What has become clear, however, is that PMCA4 - although expressed widely in most tissues - is not so much a "generic" pump for bulk $\mathrm{Ca}^{2+}$ export but rather a signaling molecule involved in highly cell-specific local $\mathrm{Ca}^{2+}$ signaling $[24,32]$. Genetic manipulation of PMCA4 expression has demonstrated the importance of this pump isoform in cardiovascular biology [32, 88]. Overexpression of PMCA4b specifically in the heart of transgenic rats and mice showed a role for this pump in the agonist-mediated hypertrophic response of cardiomyocytes, an effect mediated in part by the signaling function of PMCA4b via its physical interaction with nitric oxide synthase (nNOS) [89]. The PMCA4b/nNOSsyntrophin interaction also influences the $\beta$ adrenergic contractile response in cardiomyocytes; overexpression of PMCA4b resulted in a decreased contractile response by affecting NOS-dependent cGMP/cAMP signaling [90, 91]. Inducible overexpression of PMCA $4 \mathrm{~b}$ in the mouse heart also antagonized pressure overload-induced cardiac hypertrophy due to the interaction of PMCA4b with calcineurin [43] and the resulting decrease in NFAT signaling [92]. Accordingly, adult Atp2b4-/(PMCA4 knockout) mice showed a slight increase in heart weight and pressure overload-dependent cardiac hypertrophy [92]. On the other hand, overexpression of PMCA4b in vascular (arterial) smooth muscles of transgenic mice resulted in increased blood pressure related to the PMCA4mediated inhibition of NOS function [93, 94]. Further evidence for the importance of PMCA4 in (human) disease stems from a recent genome-wide association study (GWAS) comparing severe malaria patients and controls from large African 
population cohorts. This study found a strong association of multiple SNPs (single nucleotide polymorphisms) within the ATP2B4 gene with severe malaria [95], suggesting that alteration of PMCA4 expression or structure/function contributes to the susceptibility and resistance to severe malaria. Importantly, PMCA4 is the major PMCA isoform of human erythrocytes, contributing over $70 \%$ of the total PMCA in this tissue [53].

\section{Indirect Causes: Overexpression, Down- Regulation, Altered Localization and Dysregulation}

There is now a large literature on the correlation of altered expression, localization, regulation and function of different PMCA isoforms with pathophysiological processes. While correlation should not be equated with causality, the strong association of the change in a specific PMCA with a distinct phenotypic outcome suggests at least an indirect contribution of altered pump function to the observed outcome. The studies using knockdown approaches (using antisense oligonucleotides, siRNAs) or overexpression (by transient and stable transfection of cells in culture) are too numerous to describe individually but they have provided unequivocal evidence for the selective role(s) that different PMCA isoforms and splice variants play in processes such as cell differentiation, cell proliferation, protection against excitotoxicity and apoptosis, or regulation of amplitude and frequency of agonist-evoked $\mathrm{Ca}^{2+}$ signals in different cell types [47, 61, 96-101]. A recent study nicely demonstrated the different roles of PMCA1 and PMCA4 in bulk $\mathrm{Ca}^{2+}$ handling and the regulation of cell death pathways in the same MDA-MB-231 breast cancer cell line [63]. Studies on tissues and cells reflecting different diseases including diabetes, osteoporosis, hypercalciuria, hypertension, cancer, and neurodegenerative disease suggest that different PMCA isoforms play central roles in the pathological outcomes, although in most cases their altered expression and regulation is probably a consequence, rather than the cause, of the underlying disease [7, 102-105]. Nevertheless, the specific link of different PMCAs with defined signaling outcomes suggests that pharmacological targeting of these pumps should be of therapeutic interest $[104,106]$. For example, robust changes in the expression of PMCA1, 2, and 4 have been reported in several cancers, e.g., breast and colon, leading to remodeling of cellular $\mathrm{Ca}^{2+}$ handling and subsequent changes in gene transcription, cell differentiation and proliferation [107-111]. Because silencing of PMCA1 and PMCA4 has different consequences on cell viability and apoptotic response to toxic stress [63], targeting the individual PMCA isoforms may be useful as a tailored approach in therapeutic applications.

\section{PMCA ISOFORMS AS THERAPEUTIC TARGETS}

\section{Challenges for the Development of Specific PMCA Inhibitors}

The PMCAs are integral membrane proteins like many receptors and ion channels that have long been recognized as a major class of drug targets. Given the overwhelming evidence for the specific involvement of PMCAs in disease, why is there not a single drug on the market targeting these proteins specifically? To answer this question, it is useful to consider some of the peculiar features of the PMCAs. Unlike traditional ligand-dependent receptors or ligand-gated channels, the PMCAs have no specific peptide or small molecule extracellular ligand and hence there is no obvious targetable binding site for agonist or antagonist development from the outside of the cell. Most of the mass of the PMCAs is intracellular (see, e.g., Fig. 2), with only short extracellular loops connecting adjacent transmembrane domains. Thus, there is only limited access to the protein from the outside for possible drug targeting. The generally low abundance of the PMCAs in natural cell membranes, together with the difficulty of purifying or enriching them in an intact form, and the fact that most cells express more than one isoform have further hampered attempts to develop specific PMCA modulators. Although pump function can be relatively easily assayed (e.g., as enzymatic $\mathrm{Ca}^{2+}$ dependent ATPase activity or ${ }^{45} \mathrm{Ca}^{2+}$ uptake into microsomal vesicles), the low amount of PMCA in the membrane raises signal-to-noise issues due to the presence of contaminating ATPases. The large diversity of isoforms and splice variants presents a further challenge to the development of selective PMCA modulators. In this context, the lack of highresolution structural information on much of the PMCA molecule has been a further serious impediment to the rational design of modulators of pump function (but see below for recent advances and new opportunities). 
Generic PMCA Inhibitors Lack Specificity

Several small molecule inhibitors of PMCA function have been in use for over 30 years and have been extensively applied to block the pumps in applications ranging from in vitro $\mathrm{Ca}^{2+}$ uptake studies to physiological studies evaluating the contribution of the PMCAs to cellular $\mathrm{Ca}^{2+}$ homeostasis and specific $\mathrm{Ca}^{2+}$-dependent events such as neurotransmitter release or epithelial $\mathrm{Ca}^{2+}$ transport [13, 112]. The most frequently used strategies to block PMCA function are $\mathrm{La}^{3+}$, orthovanadate, fluorescein analogs (e.g., (carboxy)eosin), extracellular alkalization, and antagonizing calmodulin action (trifluoperazine, calmidazolium). These agents can be grouped into the 4 major categories of inorganic ions $\left(\mathrm{La}^{3+}, \mathrm{VO}_{3}{ }^{-}\right)$, molecules interacting with amino acid side chains (eosin), calmodulin antagonists, and thermodynamics-based blockade of counterion transport (reduced availability of protons due to alkalization). These modulators obviously work by very different mechanisms: $\mathrm{La}^{3+}$ blocks the conformational transition of the phosphorylated pump from the E1$\mathrm{P}$ to the E2-P state [113]; orthovanadate acts as a transition state analog of phosphate and blocks the E2 to E1 step of the pump cycle [114]; eosin and other fluorescein analogs interact with the ATP binding site [115]; and calmidazolium (and other calmodulin antagonists) prevent calmodulinstimulation of the PMCA but may also inhibit by direct interaction with the pump [116, 117]. Although all of these inhibitors are small, easy to use in most cellular applications, and relatively inexpensive, they are all non-specific with significant "off-target" effects (e.g., calmodulin inhibitors!) and most importantly, they are not isoform-selective.

\section{Development of Antibodies and Inhibitory Peptides with Isoform Specificity}

Both polyclonal and monoclonal antibodies have been raised against different PMCA isoforms [17, 118-123] and have found widespread use in applications ranging from mapping of structural domains to tissue expression and cellular localization studies. When the epitopes for several of the monoclonal antibodies were delineated [122, 124-126], only two antibodies recognized extracellular peptide sequences $[119,122]$ and very few affected pump function, either modestly stimulating or partially inhibiting $\mathrm{Ca}^{2+}$ ATPase activity $[119,120,124]$. Because of the very limited accessibility of the PMCAs from the extracellular side, raising antibodies recognizing the PMCAs on intact cells has been challenging. Perhaps more unexpected is the apparent difficulty of generating high-affinity antibodies that inhibit PMCA function. Antibodies thus appear to be of limited usefulness as pump modulators.

A more promising strategy to develop PMCAspecific inhibitors was introduced by Ashok Grover, whose laboratory focused on isolating short ( $\sim 10-15$ residues) PMCA-binding peptides by panning of random peptide phage display libraries with specific PMCA sequences corresponding to the pump's extracellular loop regions [127]. These so-called caloxins (for extracellular plasma membrane $\mathrm{Ca}^{2+}$ pump inhibitors, in analogy to the $\mathrm{Na}^{+} / \mathrm{K}^{+}$pump inhibitor digoxin) act as allosteric modulators of the PMCA presumably by interfering with important conformational transitions that occur during normal pump function [128]. Caloxins against the first, second and third extracellular loop of the PMCA (see Fig. 1) have been developed and accordingly were named caloxins 1, 2, and 3, respectively (see [127] for explanation of the caloxin nomenclature). While first generation caloxins are not very isoform-specific and have relatively high $\mathrm{K}_{\mathrm{i}}$ values on the order of $0.5 \mathrm{mM}$ (e.g., caloxin 2A1 [129]), the more recently developed caloxins (e.g., caloxin 1B1) show considerable isoform-selectivity and improved (lower) $\mathrm{K}_{\mathrm{i}}$ values $(\sim 50 \mu \mathrm{M})$ when added to the medium of intact cells [130]. Improved affinity and isoform selectivity were achieved by increasing the stringency of screening (using the full-length PMCA in addition to the synthetic PMCA peptides as target) and introducing selective amino acid changes to further optimize the caloxins. This has resulted in the $\mathrm{B}-$ and $\mathrm{C}$-series caloxins, respectively, e.g., caloxins $1 \mathrm{~B} 1$ and $1 \mathrm{C} 1[130,131]$. Considerable isoform-selectivity has been reported for some of these newer caloxins, with caloxin 1B1 showing about 2-fold higher efficacy against PMCA4 than PMCA1 [130] and caloxin 1B3 being more effective against PMCA1 $\left(\mathrm{K}_{\mathrm{i}} \sim 17 \mu \mathrm{M}\right)$ than against PMCA4 $\left(\mathrm{K}_{\mathrm{i}} \sim 45 \mu \mathrm{M}\right)$ [132]. The value of these more selective caloxins for whole-cell physiological studies of PMCA isoform function has been demonstrated in several recent publications, e.g., showing the importance of PMCA1 in endothelial cell $\mathrm{Ca}^{2+}$ regulation [132] and of PMCA4 in aortic smooth muscle contraction $[130,131]$. Caloxins with $\mathrm{K}_{\mathrm{i}}$ values in the low 
micromolar range are now available [127] and it is realistic to expect that further improvements in selection strategies and/or chemical modification will lead to the development of new generations of caloxins with even higher affinity and selectivity for specific PMCA isoforms.

\section{High-throughput Chemical Library Screening}

The need for relatively large amounts of highly purified and functional PMCA has been a major hurdle in the development of high-throughput assays. This is especially true for isoform- or splice variant-specific screenings because there is no natural tissue source that expresses only a single PMCA, and over-expression and purification of recombinant PMCAs in eukaryotic systems are not trivial. However, the minimization of assay volumes (in nanodrops or sub-nanoliter compartments) and increasingly sensitive detection methods for assay output (e.g., fluorescence-based enzymatic assay for product release) should help to mitigate this problem. Indeed, the idea of performing high-throughput screens for PMCA inhibitors has already been proposed as a desirable and viable strategy to identify specific inhibitors of PMCA4 in the treatment of cardiovascular disease [88] and in male fertility control [87]. The first proof-of-principle study describing an assay that may be suitable for the high-throughput screening of large libraries of small compounds as modulators of PMCA4 function is reported in this Special Issue of the Journal of Pharmacy and Pharmaceutical Sciences [133], showing the promise of this approach for the discovery of novel and specific PMCA modulators. Importantly, such assays can (and should) be geared towards identifying both inhibitors and activators of specific PMCAs because different pathological conditions will require antagonists to suppress the activity of a specific PMCA isoform (e.g., PMCA4 in sperm) or agonists to selectively increase a pump's activity (e.g., PMCA2 in hearing).

\section{FUTURE PROSPECTS}

The evidence for the involvement of specific PMCA isoforms and splice variants in diverse human pathologies is overwhelming, reflecting their tissue-, developmental-, and context-specific contribution to normal $\mathrm{Ca}^{2+}$ handling and their integration in complex $\mathrm{Ca}^{2+}$ signaling events. With our increased understanding of where, when, and why a specific PMCA isoform is required in normal cell function and how this may change in disease, it is now clear that the PMCAs should be considered as novel targets for therapeutic intervention. Both, inhibitors and activators are needed to modulate the activity of specific PMCAs. While it is generally simpler and more straightforward to identify and develop inhibitors of an enzyme, the unique regulation of the PMCAs opens equally promising avenues for the development of activators. This is so because the PMCAs are intrinsically autoinhibited, i.e., they are normally in a low-activity basal state and need to be activated (by calmodulin, phosphorylation, acidic phospholipids, oligomerization) to increase their $\mathrm{Ca}^{2+}$ extrusion rate. In addition, the specific association of different PMCAs with scaffolding, regulatory and signaling proteins via direct protein-protein interactions [24, 45, 134] opens the door to targeting these interactions as a means to modulate PMCA function. The delineation of specific proteinbinding domains in the PMCAs is facilitating random screenings of high-throughput small molecule libraries but is also helping with the development of rationally designed compounds because atomic resolution structures are more easily obtained for defined soluble protein-binding subdomains than of the entire PMCA membrane protein. The regulatory C-tail of the PMCAs is of particular interest because it contains multiple protein-binding domains including the calmodulinbinding and PDZ protein-interacting domains as well as domain(s) involved in the auto-inhibitory interaction with the cytosolic loops of the pump. The NMR solution structure of the calmodulinbinding domain of PMCA $4 \mathrm{~b}$ bound to calmodulin has been reported in 2010 [135] and an X-ray crystal structure of the $A$. thaliana PMCA regulatory domain in complex with two calmodulin molecules has been determined even more recently [136]. Similarly, structures of the complex of specific PDZ domains with the PDZ proteininteracting $\mathrm{C}$-terminal tail of different PMCA isoforms should soon become available, further demonstrating the feasibility of high-resolution structural information on specific domains of the PMCAs. Moreover, the structural homology of the PMCAs to the SERCA (sarco/endoplasmic reticulum $\mathrm{Ca}^{2+}$ ATPase) pumps, for which multiple X-ray crystal structures have been obtained in different conformational states $[137,138]$, is further assisting with structural studies of the PMCAs. 
Combined with increasingly sophisticated molecular modeling and biophysical and functional data from mutagenesis experiments, this is resulting in structural models (Figure 3) that may serve as a framework for further studies focusing on the development of modulators targeting specific domains of the PMCA for functional intervention.

While the PMCAs remain challenging targets for the development of modulating agents, the discovery of isoform-specific protein-protein interactions involving defined PMCA domains, combined with increasing structural information on these domains and their protein complexes, will undoubtedly lead to increased efforts to identify selective inhibitors and activators of these important membrane transporters. It is attractive to envision the not-too-distant future where PMCA modulators are part of a physician's arsenal of pharmaceutical tools in the treatment of diseases ranging from cardiovascular and neurological disorders to cancer and osteoporosis.

\section{ACKNOWLEDGEMENTS}

I thank the many coworkers and long-term collaborators who have contributed to the work of my laboratory in the past, especially Ariel J. Caride, Steven J. DeMarco, Ágnes Enyedi, Adelaida G. Filoteo, John T. Penniston, Jean-Paul F.C. Rossi, Stanley A. Thayer, Richard J. Weinberg and David A. Zacharias. The work in my laboratory has been funded in part by grants from the National Institutes of Health (RO1 GM28835 and RO1 NS51769) and the Mayo Foundation for Medical Research and Education.
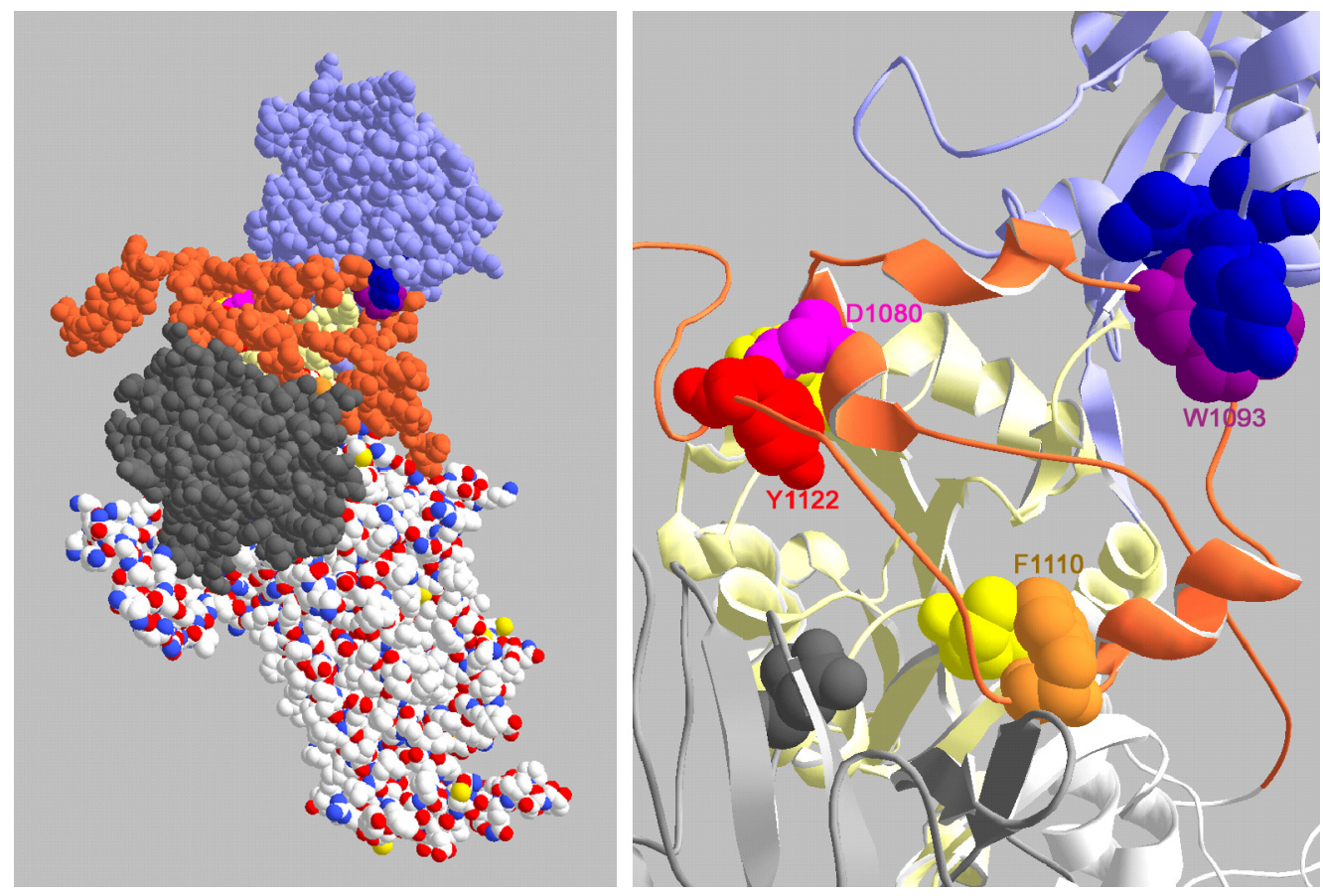

Figure 3. Model of PMCA4b in the $\mathrm{E} 1-\mathrm{Ca}^{2+}$ state highlighting intramolecular autoinhibitory interactions. A structural model was built for the PMCA4b based on its homology to SERCA, and taking into account experimental constraints derived from mutagenesis and crosslinking data. A space-filling representation of the model is on the left, and it shows how the C-tail (orange-brown) fits in the bottom of a cleft, lying on the surface of the pale yellow P domain, between the grey A domain and the light blue $\mathrm{N}$ domain. The stalk and transmembrane portions of the molecule are shown in CPK colors. Note that the cytosolic side is on top and the extracellular side on the bottom in this model. The right-hand panel shows specific interactions of the C-tail with the core; it is enlarged, but has the same orientation and colors as the left panel. This is a ribbon representation with the interacting residues shown as space-filling for emphasis. The interacting residues in the $\mathrm{C}$ tail are highlighted in color $\left(\mathrm{D}_{1080}\right.$, magenta; $\mathrm{W}_{1093}$, purple; $\mathrm{F}_{1110}$, pale orange; $\mathrm{Y}_{1122}$, red); the core residues they interact with are shown as space-filling in the same colors as the domain they are part of, but their colors are more intense. The left panel shows that the appropriate parts of C-tail are partly buried in the E1-Ca ${ }^{2+}$ state. Figure courtesy of Dr. John T. Penniston. 


\section{REFERENCES}

1. Pedersen PL, Carafoli E. (1987) Ion motive ATPases. I. Ubiquity, properties, and significance to cell function. Trends Biochem. Sci., 12, 146-150.

2. Moeller JV, Juul B, Le Maire M. (1996) Structural organization, ion transport, and energy transduction of P-type ATPases. Biochim. Biophys. Acta, 1286, $1-51$.

3. Palmgren MG, Nissen P. (2011) P-type ATPases. Ann. Rev. Biophys., 40, 243-266.

4. Axelsen KB, Palmgren MG. (1998) Evolution of substrate specificities in the P-type ATPase superfamily. J. Mol. Evol., 46, 84-101.

5. Thever MD, Saier MH. (2009) Bioinformatic characterization of P-type ATPases encoded within the fully sequenced genomes of 26 eukaryotes. J. Membr. Biol., 229, 115-130.

6. Strehler EE, Zacharias DA. (2001) Role of alternative splicing in generating isoform diversity among plasma membrane calcium pumps. Physiol. Rev., 81, 21-50.

7. Brini M, Carafoli E. (2009) Calcium pumps in health and disease. Physiol. Rev., 89, 1341-1378.

8. Monteith GR, Roufogalis BD. (1995) The plasma membrane calcium pump - a physiological perspective on its regulation. Cell Calcium, 18, 459470.

9. Penniston JT, Enyedi A. (1998) Modulation of the plasma membrane $\mathrm{Ca}^{2+}$ pump. J. Membr. Biol., 165, 101-109.

10. Strehler EE, Treiman M. (2004) Calcium pumps of plasma membrane and cell interior. Curr. Mol. Med., 4, 323-335.

11. Di Leva F, Domi T, Fedrizzi L, Lim D, Carafoli E. (2008) The plasma membrane $\mathrm{Ca}^{2+}$ ATPase of animal cells: Structure, function and regulation. Arch. Biochem. Biophys., 476, 65-74.

12. Schatzmann HJ. (1982) The plasma membrane calcium pump of erythrocytes and other animal cells. In: Membrane Transport of Calcium (ed. E Carafoli). Academic Press, London.

13. Carafoli E. (1991) Calcium pump of the plasma membrane. Physiol. Rev., 71, 129-153.

14. Brandt P, Neve RL, Kammesheidt A, Rhoads RE, Vanaman TC. (1992) Analysis of the tissue-specific distribution of mRNAs encoding the plasma membrane calcium-pumping ATPases and characterization of an alternately spliced form of PMCA4 at the cDNA and genomic levels. J. Biol. Chem., 267, 4367-4385.

15. Keeton TP, Burk SE, Shull GE. (1993) Alternative splicing of exons encoding the calmodulin-binding domains and C-termini of plasma membrane $\mathrm{Ca}^{2+}-$ ATPase isoforms 1,2,3, and 4. J. Biol. Chem., 268, 2740-2748.
16. Stauffer TP, Hilfiker H, Carafoli E, Strehler EE. (1993) Quantitative analysis of alternative splicing options of human plasma membrane calcium pump genes [published erratum appears in J. Biol. Chem. 269:32022 (1994)]. J. Biol. Chem., 268, 2599326003.

17. Stauffer TP, Guerini D, Carafoli E. (1995) Tissue distribution of the four gene products of the plasma membrane $\mathrm{Ca}^{2+}$ pump. A study using specific antibodies. J. Biol. Chem., 270, 12184-12190.

18. Zacharias DA, Kappen C. (1999) Developmental expression of the four plasma membrane calcium ATPase (Pmca) genes in the mouse. Biochim. Biophys. Acta, 1428, 397-405.

19. Brandt P, Neve RL. (1992) Expression of plasma membrane calcium-pumping ATPase mRNAs in developing rat brain and adult brain subregions: Evidence for stage-specific expression. J. Neurochem., 59, 1566-1569.

20. Brandt P, Vanaman TC. (1994) Splicing of the muscle-specific plasma membrane $\mathrm{Ca}^{2+}$-ATPase isoform PMCA1c is associated with cell fusion in C2 myocytes. J. Neurochem., 62, 799-802.

21. Kenyon KA, Bushong EA, Mauer AS, Strehler EE, Weinberg RJ, Burette AC. (2010) Cellular and subcellular localizatin of the neuron-specific plasma membrane calcium ATPase PMCA1a in the rat brain. J. Comp. Neurol., 518, 3169-3183.

22. Stahl WL, Eakin TJ, Owens JWM, Breininger JF, Filuk PE, Anderson WR. (1992) Plasma membrane $\mathrm{Ca}^{2+}$-ATPase isoforms: distribution of mRNAs in rat brain by in situ hybridization. Molec. Brain Res., 16, 223-231.

23. Burette A, Rockwood JM, Strehler EE, Weinberg RJ. (2003) Isoform-specific distribution of the plasma membrane $\mathrm{Ca}^{2+}$ ATPase in the rat brain. J. Comp. Neurol., 467, 464-476.

24. Strehler EE, Caride AJ, Filoteo AG, Xiong Y, Penniston JT, Enyedi Á. (2007) Plasma membrane $\mathrm{Ca}^{2+}$ ATPases as dynamic regulators of cellular calcium handling. Ann. N. Y. Acad. Sci., 1099, 226236.

25. Krizaj D, DeMarco SJ, Johnson J, Strehler EE, Copenhagen DR. (2002) Cell-specific expression of plasma membrane calcium ATPase isoforms in retinal neurons. J. Comp. Neurol., 451, 1-21.

26. Dumont RA, Lins U, Filoteo AG, Penniston JT, Kachar B, Gillespie PG. (2001) Plasma membrane $\mathrm{Ca}^{2+}$ ATPase isoform 2a is the PMCA of hair bundles. J. Neurosci., 21, 5066-5078.

27. Caride AJ, Elwess NL, Verma AK, Filoteo AG, Enyedi Á, Bajzer Z, Penniston JT. (1999) The rate of activation by calmodulin of isoform 4 of the plasma membrane $\mathrm{Ca}^{2+}$ pump is slow and is changed by alternative splicing. J. Biol. Chem., 274, 3522735232 . 
28. Caride AJ, Penheiter AR, Filoteo AG, Bajzer Z, Enyedi Á, Penniston JT. (2001) The plasma membrane calcium pump displays memory of past calcium spikes. Differences between isoforms $2 \mathrm{~b}$ and 4b. J. Biol. Chem., 276, 39797-39804.

29. Caride AJ, Filoteo AG, Penniston JT, Strehler EE. (2007) The plasma membrane $\mathrm{Ca}^{2+}$ pump isoform $4 \mathrm{a}$ differs from isoform $4 \mathrm{~b}$ in the mechanism of calmodulin binding and activation kinetics. J. Biol. Chem., 282, 25640-25648.

30. Enyedi A, Verma AK, Heim R, Adamo HP, Filoteo AG, Strehler EE, Penniston JT. (1994) The $\mathrm{Ca}^{2+}$ affinity of the plasma membrane $\mathrm{Ca}^{2+}$ pump is controlled by alternative splicing. J. Biol. Chem., 269, 41-43.

31. Garside ML, Turner PR, Austen B, Strehler EE, Beesley PW, Empson RM. (2009) Molecular interactions of the plasma membrane calcium ATPase 2 at pre-and post-synaptic sites in rat cerebellum. Neuroscience, 162, 383-395.

32. Oceandy D, Mohamed TMA, Cartwright EJ, Neyses L. (2011) Local signals with global impacts and clinical implications: Lessons from the plasma membrane calcium pump (PMCA4). Biochim. Biophys. Acta, 1813, 974-978.

33. Kim E, DeMarco SJ, Marfatia SM, Chishti AH, Sheng M, Strehler EE. (1998) Plasma membrane $\mathrm{Ca}^{2+}$ ATPase isoform $4 \mathrm{~b}$ binds to membraneassociated guanylate kinase (MAGUK) proteins via their PDZ (PSD-95/Dlg/ZO-1) domains. J. Biol. Chem., 273, 1591-1595.

34. DeMarco SJ, Strehler EE. (2001) Plasma membrane $\mathrm{Ca}^{2+}$-ATPase isoforms $2 \mathrm{~b}$ and $4 \mathrm{~b}$ interact promiscuously and selectively with members of the membrane-associated guanylate kinase family of PDZ (PSD-95/Dlg/ZO-1) domain-containing proteins. J. Biol. Chem., 276, 21594-21600.

35. Schuh K, Uldrijan S, Gambaryan S, Roethlein N, Neyses L. (2003) Interaction of the plasma membrane $\mathrm{Ca}^{2+}$ pump $4 \mathrm{~b} / \mathrm{CI}$ with the $\mathrm{Ca}^{2+} /$ calmodulin-dependent membrane-associated kinase CASK. J. Biol. Chem., 278, 9778-9883.

36. Bozulic LD, Malik MT, Powell DW, Nanez A, Link AJ, Ramos KS, Dean WL. (2007) Plasma membrane $\mathrm{Ca}(2+)$-ATPase associates with CLP36, alphaactinin and actin in human platelets. Thromb. Haemost., 97, 587-597.

37. DeMarco SJ, Chicka MC, Strehler EE. (2002) Plasma membrane $\mathrm{Ca}^{2+}$ ATPase isoform $2 b$ interacts preferentially with $\mathrm{Na}^{+} / \mathrm{H}^{+}$exchanger regulatory factor 2 in apical plasma membranes. J. Biol. Chem., 277, 10506-10511.

38. Goellner GM, DeMarco SJ, Strehler EE. (2003) Characterization of PISP, a novel single-PDZ protein that binds to all plasma membrane $\mathrm{Ca}^{2+}$ ATPase b-splice variants. Ann. N. Y. Acad. Sci., 986, 461-471.
39. Schuh K, Uldrijan S, Telkamp M, Röthlein N, Neyses L. (2001) The plasmamembrane calmodulindependent calcium pump: a major regulator of nitric oxide synthase I. J. Cell Biol., 155, 201-205.

40. Sgambato-Faure V, Xiong Y, Berke JD, Hyman SE, Strehler EE. (2006) The homer-1 protein Ania-3 interacts with the plasma membrane calcium pump. Biochem. Biophys. Res. Commun., 343, 630-637.

41. Rimessi A, Coletto L, Pinton P, Rizzuto R, Brini M, Carafoli E. (2005) Inhibitory interaction of the 14-3$3 \mathrm{e}$ protein with isoform 4 of the plasma membrane $\mathrm{Ca}^{2+}$-ATPase pump. J. Biol. Chem., 280, 3719537203.

42. Armesilla AL, Williams JC, Buch MH, Pickard A, Emerson M, Cartwright EJ, Oceandy D, Vos MD, Gillies S, Clark GJ, Neyses L. (2004) Novel functional interaction between the plasma membrane $\mathrm{Ca}^{2+}$ pump $4 \mathrm{~b}$ and the proapoptotic tumor suppressor Ras-associated factor 1 (RASSF1). J. Biol. Chem., 279, 31318-31328.

43. Buch MH, Pickard A, Rodriguez A, Gillies S, Maass $\mathrm{AH}$, Emerson M, Cartwright EJ, Williams JC, Oceandy D, Redondo JM, Neyses L, Armesilla AL. (2005) The sarcolemmal calcium pump inhibits the calcineurin/nuclear factor of activated T-cell pathway via interaction with the calcineurin A catalytic subunit. J. Biol. Chem., 280, 29479-29487.

44. Williams JC, Armesilla AL, Mohamed TMA, Hagarty CL, McIntyre FH, Schomburg S, Zaki AO, Oceandy D, Cartwright EJ, Buch MH, Emerson M, Neyses L. (2006) The sarcolemmal calcium pump, a-1 syntrophin, and neuronal nitric-oxide synthase are parts of a macromolecular protein complex. J. Biol. Chem., 281, 23341-23348.

45. Kruger WA, Monteith GR, Poronnik P. (2010) The plasma membrane $\mathrm{Ca}^{2+}$-ATPase: Regulation by PSD-95/Dlg/Zo-1 scaffolds. Int. J. Biochem. Cell Biol., 42, 805-808.

46. Padányi R, Xiong Y, Antalffy G, Lór K, Pászty K, Strehler EE, Enyedi A. (2010) Apical scaffolding protein NHERF2 modulates the localization of alternatively spliced plasma membrane $\mathrm{Ca}^{2+}$ pump $2 \mathrm{~b}$ variants in polarized epithelial cells. J. Biol. Chem., 285, 31704-31712.

47. Gómez-Varela D, Schnidt M, Schoellerman J, Peters EC, Berg DK. (2012) PMCA2 via PSD-95 controls calcium signaling by a7-containing nicotinic acetylcholine receptors on aspiny interneurons. J. Neurosci., 32, 6894-6905.

48. Ritchie MF, Samakai E, Soboloff J. (2012) STIM1 is required for attenuation of PMCA-mediated $\mathrm{Ca}^{2+}$ clearance during T-cell activation. EMBO J., 31, 1123-1133.

49. Niggli V, Adunyah ES, Penniston JT, Carafoli E. (1981) Purified $\left(\mathrm{Ca}^{2+} \mathrm{Mg}^{2+}\right)$-ATPase of the erythrocyte membrane: reconstitution and effect of 
calmodulin and phospholipids. J. Biol. Chem., 256, 395-401.

50. Niggli V, Adunyah ES, Carafoli E. (1981) Acidic phospholipids, unsaturated fatty acids and proteolysis mimic the effect of calmodulin on the purified erythrocyte $\mathrm{Ca}^{2+}$-ATPase. J. Biol. Chem., 256, 8588-8592.

51. Enyedi A, Flura M, Sarkadi B, Gardos G, Carafoli E. (1987) The maximum velocity and the calcium affinity of the red cell calcium pump may be regulated independently. J. Biol. Chem., 262, 64256430.

52. Carafoli E. (1994) Biogenesis: Plasma membrane calcium ATPase: 15 years of work on the purified enzyme. FASEB J., 8, 993-1002.

53. Strehler EE, James P, Fischer R, Heim R, Vorherr T, Filoteo AG, Penniston JT, Carafoli E. (1990) Peptide sequence analysis and molecular cloning reveal two calcium pump isoforms in the human erythrocyte membrane. J. Bio. Chem., 265, 28352842.

54. Adamo HP, Verma AK, Sanders MA, Heim R, Salisbury JL, Wieben ED, Penniston JT. (1992) Overexpression of the erythrocyte plasma membrane $\mathrm{Ca}^{2+}$ pump in COS-1 cells. Biochem. J., 285, 791797.

55. Corradi GR, Adamo HP. (2007) Intramolecular fluorescence resonance energy transfer between fused autofluorescent proteins reveals rearrangements of the $\mathrm{N}$ - and $\mathrm{C}$-terminal segments of the plasma membrane $\mathrm{Ca}^{2+}$ pump involved in the activation. J. Biol. Chem., 282, 35440-35448.

56. Heim R, Iwata $T$, Zvaritch $E$, Adamo HP, Rutishauser B, Strehler EE, Guerini D, Carafoli E. (1992) Expression, purification, and properties of the plasma membrane $\mathrm{Ca}^{2+}$ pump and of its $\mathrm{N}$ terminally truncated $105-\mathrm{kDa}$ fragment. J. Bio. Chem., 267, 24476-24484.

57. Hilfiker H, Guerini D, Carafoli E. (1994) Cloning and expression of isoform 2 of the human membrane $\mathrm{Ca}^{2+}$ ATPase. J. Biol. Chem., 269, 26178-26103.

58. Caride AJ, Filoteo AG, Penheiter AR, Pászty K, Enyedi Á, Penniston JT. (2001) Delayed activation of the plasma membrane calcium pump by a sudden increase in $\mathrm{Ca}^{2+}$ : fast pumps reside in fast cells. Cell Calcium, 30, 49-57.

59. Penheiter AR, Bajzer Z, Filoteo AG, Thorogate R, Török K, Caride AJ. (2003) A model for the activation of plasma membrane calcium pump isoform $4 \mathrm{~b}$ by calmodulin. Biochemistry, 42, 1211512124.

60. Brini M, Bano D, Manni S, Rizzuto R, Carafoli E. (2000) Effects of PMCA and SERCA pump overexpression on the kinetics of cell $\mathrm{Ca}^{2+}$ signalling. EMBO J., 19, 4926-4935.

61. Brini M, Coletto L, Pierobon N, Kraev N, Guerini D, Carafoli E. (2003) A comparative functional analysis of plasma membrane $\mathrm{Ca}^{2+}$ pump isoforms in intact cells. J. Biol. Chem., 278, 24500-24508.

62. Antalffy G, Mauer AS, Pászty K, Hegedus L, Padányi R, Enyedi A, Strehler EE. (2012) Plasma membrane calcium pump (PMCA) isoform 4 is targeted to the apical membrane by the w-splice insert from PMCA2. Cell Calcium, 51, 171-178.

63. Curry MC, Luk NA, Kenny PA, Roberts-Thomson SJ, Monteith GR. (2012) Distinct regulation of cytoplasmic calcium signals and cell death pathways by different plasma membrane calcium ATPase isoforms in MDA-MB-231 breast cancer cells. J. Biol. Chem., 287, 28598-28608.

64. Kozel PJ, Friedman RA, Erway LC, Yamoah EN, Liu LH, Riddle T, Duffy JJ, Doetschman T, Miller ML, Cardell EL, Shull GE. (1998) Balance and hearing deficits in mice with a null mutation in the gene encoding plasma membrane $\mathrm{Ca}^{2+}$-ATPase isoform 2. J. Biol. Chem., 273, 18693-18696.

65. Okunade GW, Miller ML, Pyne GJ, Sutliff RL, O'Connor KT, Neumann JC, Andringa A, Miller DA, Prasad V, Doetschman T, Paul RJ, Shull GE. (2004) Targeted ablation of plasma membrane $\mathrm{Ca}^{2+}$ ATPase (PMCA) 1 and 4 indicates a major housekeeping function for PMCA1 and a critical role in hyperactivated sperm motility and male fertility for PMCA4. J. Biol. Chem., 279, 3374233750.

66. Schuh K, Cartwright EJ, Jankevics E, Bundschu K, Liebermann J, Williams JC, Armesilla AL, Emerson M, Oceandy D, Knobeloch K-P, Neyses L. (2004) Plasma membrane $\mathrm{Ca}^{2+}$ ATPase 4 is required for sperm motility and male fertility. J. Biol. Chem., 279, 28220-28226.

67. Prasad V, Okunade G, Liu L, Paul RJ, Shull GE. (2007) Distinct phenotypes among plasma membrane $\mathrm{Ca}^{2+}$-ATPase knockout mice. Ann. N. Y. Acad. Sci., 1099, 276-286.

68. Liu L, Ishida Y, Okunade G, Shull GE, Paul RJ. (2006) Role of plasma membrane $\mathrm{Ca}^{2+}$-ATPase in contraction-relaxation processes of the bladder: evidence from PMCA gene-ablated mice. Am. J. Physiol., 290, C1239-C1247.

69. Liu L, Ishida Y, Okunade G, Pyne-Geithman GJ, Shull GE, Paul RJ. (2007) Distinct roles of PMCA isoforms in $\mathrm{Ca}^{2+}$ homeostasis of bladder smooth muscle: evidence from PMCA gene-ablated mice. Am. J. Physiol., 292, C423-C431.

70. Kohara K, Tabara Y, J. N, Imai Y, Ohkubo T, Hata A, Soma M, Nakayama T, Umemura S, Hirawa N, Ueshima H, Kita Y, Igihara t, Katsuya T, Takahashi N, Tokunaga K, Miki T. (2008) Identification of hypertension-susceptibility genes and pathways by a systemic multiple candidate gene approach: the Millennium Genome Project for Hypertension. Hypertension Res., 31, 203-212. 
71. The International Consortium for Blood Pressure Genome-Wide Association Studies. (2011) Genetic variants in novel pathways influence blood pressure and cardiovascular disease risk. Nature, 478, 103109.

72. Kobayashi Y, Hirawa N, Tabara Y, Muraoka H, Fujita M, Miyazaki N, Fujiwara A, Ichikawa Y, Yamamoto Y, Ichihara N, Saka S, Wakui H, Yoshida S, Yatsu K, Toya Y, Yasuda G, Kohara K, Kita Y, Takei K, Goshima Y, Ishikawa Y, Ueshima H, Miki T, Umemura S. (2012) Mice lacking hypertension candidate gene Atp2b1 in vascular smooth muscle cells show significant blood pressure elevation. Hypertension, 59, 854-860.

73. Street VA, McKee-Johnson JW, Fonseca RC, Tempel BL, Noben-Trauth K. (1998) Mutations in a plasma membrane $\mathrm{Ca}^{2+}$-ATPase gene cause deafness in deafwaddler mice. Nature Genet., 19, 390-394.

74. Takahashi K, Kitamura K. (1999) A point mutation in a plasma membrane $\mathrm{Ca}^{2+}$-ATPase gene causes deafness in Wriggle Mouse Sagami. Biochem. Biophys. Res. Commun., 261, 773-778.

75. Sun X, Chen Z, Hayashi Y, Kanou Y, Takagishi Y, Oda S, Murata Y. (2008) Insertion of an intracisternal A particle retrotransposon element in plasma membrane calcium ATPase 2 gene attenuates its expression and produces an ataxic phenotype in joggle mutant mice. Gene, 41, 94-102.

76. Spiden SL, Bortolozzi M, Di Leva F, de Angelis MH, Fuchs H, Lim D, Ortolano S, Ingham NJ, Brini M, Carafoli E, Mammano F, Steel KP. (2008) The novel mouse mutation oblivion inactivates the PMCA2 pump and causes progressive hearing loss. PLoS Genetics, 4, e1000238.

77. Giacomello M, De Mario A, Primerano S, Brini M, Carafoli E. (2012) Hair cells, plasma membrane $\mathrm{Ca}^{2+}$ ATPase and deafness. Int. J. Biochem. Cell Biol., 44, 679-683.

78. Reinhardt TA, Lippolis JD, Shull GE, Horst RL. (2004) Null mutation in the gene encoding plasma membrane $\mathrm{Ca}^{2+}$-ATPase isoform 2 impairs calcium transport into milk. J. Biol. Chem., 279, 4236942373.

79. Kurnellas MP, Lee AK, Li H, Deng L, Ehrlich DJ, Elkabes S. (2007) Molecular alterations in the cerebellum of the plasma membrane calcium ATPase 2 (PMCA2)-null mouse indicate abnormalities in Purkinje neurons. Mol. Cell. Neurosci., 34, 178-188.

80. Empson RM, Garside ML, Knöpfel T. (2007) Plasma membrane $\mathrm{Ca}^{2+}$ ATPase 2 contributes to short-term synapse plasticity at the parallel fibre to Purkinje neurone synapse. J. Neurosci., 27, 37533758.

81. Empson RM, Turner PR, Nagaraja RY, Beesley PW, Knöpfel T. (2010) Reduced expression of the $\mathrm{Ca}^{2+}$ transporter protein PMCA2 slows $\mathrm{Ca}^{2+}$ dynamics in mouse cerebellar Purkinje neurones and alters the precision of motor coordination. J. Physiol., 588.6, 907-922.

82. Huang H, Nagaraja RY, Garside ML, Akemann W, Knöpfel T, Empson RM. (2010) Contribution of plasma membrane $\mathrm{Ca}^{2+}$ ATPase to cerebellar synapse function. World J. Biol. Chem., 1, 95-102.

83. Schultz JM, Yang Y, Caride AJ, Filoteo AG, Penheiter AR, Lagziel A, Morell RJ, Mohiddin SA, Fananapazir L, Madeo AC, Penniston JT, Griffith AJ. (2005) Modification of human hearing loss by plasma-membrane calcium pump PMCA2. New England J. of Med., 352, 1557-1564.

84. Ficarella R, Di Leva F, Bortolozzi M, Ortolano S, Donaudy F, Petrillo M, Melchionda S, Lelli A, Domi T, Fedrizzi L, Lim D, Shull GE, Gasparini P, Brini M, Mammano F, Carafoli E. (2007) A functional study of plasma-membrane calcium-pump isoform 2 mutants causing digenic deafness. Proc. Nat. Acad. Sci. U.S.A., 104, 1516-1521.

85. Zanni G, Calì T, Kalscheuer VM, Ottolini D, Barresi S, Lebrun N, Montecchi-Palazzi L, Hu H, Chelly J, Bertini E, Brini M, Carafoli E. (2012) Mutation of plasma membrane $\mathrm{Ca}^{2+}$ ATPase isoform 3 in a family with $\mathrm{X}$-linked congenital cerebellar ataxia impairs $\mathrm{Ca}^{2+}$ homeostasis. Proc. Nat. Acad. Sci. U.S.A., 109, 14514-14519.

86. Burette A, Weinberg RJ. (2007) Perisynaptic organization of plasma membrane calcium pumps in cerebellar cortex. J. Comp. Neurol., 500, 1127-1135.

87. Cartwright EJ, Neyses L. (2010) Evaluation of plasma membrane calcium/calmodulin-dependent ATPase isoform 4 as a potential target for fertility control. Handb. Exp. Pharmacol., 198, 79-95.

88. Oceandy D, Mamas MA, Neyses L. (2007) Targeting the sarcolemmal calcium pump: a potential novel strategy for the treatment of cardiovascular disease. Cardiovasc. Hematol. Agents Med. Chem., 5, 300-304.

89. Oceandy D, Cartwright EJ, Emerson M, Prehar S, Baudoin FM, Zi M, Alatwi N, Venetucci L, Schuh K, Williams JC, Armesilla AL, L. N. (2007) Neuronal nitric oxide synthase signaling in the heart is regulated by the sarcolemmal calcium pump $4 \mathrm{~b}$. Circulation, 115, 483-492.

90. Mohamed TMA, Oceandy D, Prehar S, Alatwi N, Hegab Z, Baudoin FM, Pickard A, Zaki AO, Nadif R, Cartwright EJ, Neyses L. (2009) Specific role of neuronal nitric-oxide synthase when tethered to the plasma membrane calcium pump in regulating the badrenergic signal in the myocardium. J. Biol. Chem., 284, 12091-12098.

91. Mohamed TMA, Oceandy D, Zi M, Prehar S, Alatwi N, Wang Y, Shaheen MA, Abou-Leisa R, Schelcher C, Hegab Z, Baudoin F, Emerson M, Mamas M, Di Benedetto G, Zaccolo M, Lei M, Cartwright EJ, Neyses L. (2011) Plasma membrane calcium pump 
(PMCA4)-neuronal nitric-oxide synthase complex regulates cardiac contractility through modulation of a compartmentalized cyclic nucleotide microdomain. J. Biol. Chem., 286, 41520-41529.

92. Wu X, Chang B, Blair NS, Sargent M, York AJ, Robbins J, Shull GE, Molkentin JD. (2009) Plasma membrane $\mathrm{Ca}^{2+}$-ATPase isoform 4 antagonizes cardiac hypertrophy in association with calcineurin inhibition in rodents. J. Clin. Invest., 119, 976-985.

93. Gros R, Afroze T, You X-M, Kabir G, Van Wert R, Kalair W, Hoque AE, Mungrue IN, Husain M. (2003) Plasma membrane calcium ATPase overexpression in arterial smooth muscle increases vasomotor responsiveness and blood pressure. Circ. Res., 93, 614-621.

94. Schuh K, Quaschning T, Knauer S, Hu K, Koçak S, Roethlein N, Neyses L. (2003) Regulation of vascular tone in animals overexpresing the sarcolemmal calcium pump. J. Biol. Chem., 278, 41246-41252.

95. Timmann C, Thye T, Vens M, Evans J, May J, Ehmen C, Sievertsen J, Muntau B, Ruge G, Loag W, Ansong D, Antwi S, Asafo-Adjei E, Nguah SB, Kwakye KO, Akoto AOY, Sylverken J, Brendel M, Schuldt K, Loley C, Franke A, Meyer CG, Agbenyega T, Ziegler A, Horstmann RD. (2012) Genome-wide association study indicates two novel resistance loci for severe malaria. Nature, 489, 443446.

96. Ono K, Wang X, Han J. (2001) Resistance to tumor necrosis factor-induced cell death mediated by PMCA4 deficiency. Mol. Cell. Biol., 21, 8276-8288.

97. Garcia ML, Usachev YM, Thayer SA, Strehler EE, Windebank AJ. (2001) The plasma membrane calcium ATPase plays an important role in reducing $\mathrm{Ca}^{2+}$ mediated cytotoxicity in PC12 cells. J. Neurosci. Res., 64, 661-669.

98. Sasamura S, Furukawa K-I, Shiratori M, Motomura S, Ohizumi Y. (2002) Antisense-inhibition of plasma membrane $\mathrm{Ca}^{2+}$ pump induces apoptosis in vascular smooth muscle cells. Jpn. J. Pharmacol., 90, 164-172.

99. Zylinska L, Kozaczuk A, Szemraj J, Kargas C, Kowalska I. (2007) Functional importance of PMCA isoforms in growth and development of PC12 cells. Ann. N. Y. Acad. Sci., 1099, 254-269.

100. Fernandes D, Zaidi A, Bean J, Hui D, Michaelis ML. (2007) $\mathrm{RNA}_{\mathrm{i}}$-induced silencing of the plasma membrane $\mathrm{Ca}^{2+}$-ATPase 2 in neuronal cells: effects on $\mathrm{Ca} 2+$ homeostasis and cell viability. J. Neurochem., 101, 454-465.

101. Jiang L, Allagnat F, Nguidjoe E, Kamagate A, Pachera N, Vanderwinden J-M, Brini M, Carafoli E, Eizirik DL, Cardozo AK, Herchuelz A. (2010) Plasma membrane $\mathrm{Ca}^{2+}$-ATPase overexpression depletes both mitochondrial and endoplasmic reticulum $\mathrm{Ca}^{2+}$ stores and triggers apoptosis in insulin-secreting BRIN-BD11 cells. J. Biol. Chem., 285, 30634-30643.

102. Lehotsky J, Kaplan P, Murin R, Raeymaekers L. (2002) The role of plasma membrane $\mathrm{Ca}^{2+}$ pump (PMCA) in pathologies of mammalian cells. Front. Biosci., 7, d53-84.

103. Roberts-Thomson SJ, Curry MC, Monteith GR. (2010) Plasma membrane calcium pumps and their emerging roles in cancer. World J. Biol. Chem., 1, 248-253.

104. Monteith GR, Davis FM, Roberts-Thomson SJ. (2012) Calcium channels and pumps in cancer: changes and consequences. J. Biol. Chem., 287, 31666-31673.

105. Giacomello M, De Mario A, Scarlatti C, Primerano S, Carafoli E. (2013) Plasma membrane calcium ATPases and related disorders. Int. J. Biochem. Cell Biol., 45, 753-762.

106. Monteith GR, McAndrew D, Faddy HM, RobertsThomson SJ. (2007) Calcium and cancer: targeting $\mathrm{Ca}^{2+}$ transport. Nature Rev. Cancer, 7, 519-530.

107. Lee WJ, Roberts-Thomson SJ, Monteith GR. (2005) Plasma membrane calcium-ATPase 2 and 4 in human breast cancer cell lines. Biochem. Biophys. Res. Commun., 337, 779-783.

108. Aung CS, Kruger WA, Poronnik P, RobertsThomson SJ, Monteith GR. (2007) Plasma membrane $\mathrm{Ca}^{2+}$-ATPase expression during colon cancer cell line differentiation. Biochem. Biophys. Res. Commun., 355, 932-936.

109. Ribiczey P, Tordai A, Andrikovics H, Filoteo AG, Penniston JT, Enouf J, Enyedi Á, Papp B, Kovács T. (2007) Isoform-specific up-regulation of plasma membrane $\mathrm{Ca}^{2+}$ ATPase expression during colon and gastric cancer cell differentiation. Cell Calcium, 42, 590-605.

110. Aung CS, Ye W, Plowman G, Peters AA, Monteith GR, Roberts-Thomson SJ. (2009) Plasma membrane calcium ATPase 4 and the remodeling of calcium homeostasis in human colon cancer cells. Carcinogenesis, 30, 19621969.

111. Rüschoff JH, Brandenburger $T$, Strehler EE, Filoteo AG, Heinmöller E, Aumüller G, Wilhelm B. (2012) Plasma membrane calcium ATPase expression in human colon multistep carcinogenesis. Cancer Invest., 30, 251-257.

112. Garrahan PJ, Rega AF. (1990) Plasma membrane calcium pump. In: Intracellular Calcium Regulation (ed. F Bronner), pp 271-303. Alan R. Liss.

113. Luterbacher S, Schatzmann HJ. (1983) The site of action of $\mathrm{La}^{3+}$ in the reaction cycle of the human red cell membrane $\mathrm{Ca}^{2+}$-pump ATPase. Experientia, 39, 311-312. 
114. Barrabín H, Garrahan PJ, Rega AF. (1980) Vanadate inhibition of the $\mathrm{Ca}^{2+}$-ATPase from human red cell membranes. Biochim. Biophys. Acta, 600, 796-804.

115. Gatto C, Milanick MA. (1993) Inhibition of the red blood cell calcium pump by eosin and other fluorescein analogues. Am. J. Physiol., 264, C1577-C1586.

116. Gietzen K, Wüthrich A, Bader H. (1981) R24571: a new powerful inhibitor of red blood cell $\mathrm{Ca}^{2+}$ transport ATPase and of calmodulin-regulated functions. Biochem. Biophys. Res. Commun., 101, 418-425.

117. Vincenzi FF, Adunyah ES, Niggli V, Carafoli E. (1982) Purified red blood cell $\mathrm{Ca}^{2+}$ pump ATPase: evidence for direct inhibition by presumed anticalmodulin drugs in the absence of calmodulin. Cell Calcium, 3, 545-559.

118. Borke JL, Minami J, Verma A, Penniston JT, Kumar R. (1987) Monoclonal antibodies to human erythrocyte membrane $\mathrm{Ca}++-\mathrm{Mg}++$ adenosine triphosphatase pump recognize an epitope in the basolateral membrane of human kidney distal tubule cells. J. Clin. Invest., 80, 1225-1231.

119. Caride AJ, Gorski JP, Penniston JT. (1988) Topology of the erythrocyte $\mathrm{Ca}^{2+}$ pump. A monoclonal antibody against the almost inaccessible extracellular face. Biochem. J., 255, 663-670.

120. Caride AJ, Enyedi A, Penniston JT. (1989) Inhibition of the purified human red-cell $\mathrm{Ca}^{2+}$ pump by a monoclonal antibody. Biochem. J., 264, 87-92.

121. Grover AK. (1988) Monoclonal antibody against an epitope on the cytoplasmic aspect of the plasma membrane calcium pump. J. Biol. Chem., 263, 19510-19512.

122. Feschenko MS, Zvaritch EI, Hofmann F, Shakhparonov MI, Modyanov NN, Vorheer T, Carafoli E. (1992) A monoclonal antibody recognizes an epitope in the first extracellular loop of the plasma membrane $\mathrm{Ca}^{2+}$ pump. J. Biol. Chem., 267, 4097-4101.

123. Filoteo AG, Elwess NL, Enyedi A, Caride A, Aung H-H, Penniston JT. (1997) Plasma membrane $\mathrm{Ca}^{2+}$ pump in rat brain. Patterns of alternative splices seen by isoform-specific antibodies. J. Biol. Chem., 272, 23741-23747.

124. Adamo HP, Caride AJ, Penniston JT. (1992) Use of expression mutants and monoclonal antibodies to map the erythrocyte $\mathrm{Ca}^{2+}$ pump. J. Biol. Chem., 267, 14244-14249.

125. Caride AJ, Filoteo AG, Enyedi A, Verma AK, Penniston JT. (1996) Detection of isoform 4 of the plasma membrane calcium pump in human tissues by using isoform-specific monoclonal antibodies. Biochem. J., 316, 353-359.
126. Pestov NB, Korneenko TV, Kostina MB, Shakhparonov MI. (1999) Epitope mapping for monoclonal antibodies to $\mathrm{Ca}^{2+}$-ATPase from human plasma membranes. Russ. J. Bioorg. Chem., 25, 448-454.

127. Pande J, Szewczyk MM, Grover AK. (2011) Allosteric inhibitors of plasma membrane $\mathrm{Ca}^{2+}$ pumps: Invention and applications of caloxins. World J. Biol. Chem., 2, 39-47.

128. Holmes ME, Chaudhary J, Grover AK. (2003) Mechanism of action of the novel plasma membrane $\mathrm{Ca}(2+)$-pump inhibitor caloxin. Cell Calcium, 33, 241-245.

129. Chaudhary J, Walia M, Matharu J, Escher E, Grover AK. (2001) Caloxin: a novel plasma membrane $\mathrm{Ca}^{2+}$ pump inhibitor. Am. J. Physiol., 280, C1027-C1030.

130. Pande J, Mallhi KK, Sawh A, Szewczyk MM, Simpson F, Grover AK. (2006) Aortic smooth muscle and endothelial plasma membrane $\mathrm{Ca}^{2+}$ pump isforoms are inhibited differently by the extracellular inhibitor caloxin 1b1. Am. J. Physiol., 290, C1341-C1349.

131. Pande J, Szewczyk MM, Kuszczak I, Grover S, Escher E, Grover AK. (2008) Functional effects of caloxin 1c2, a novel engineered selective inhibitor of plasma membrane $\mathrm{Ca}^{2+}$-pump isoform 4, on coronary artery. J. Cell. Mol. Med., 12, 1049-1060.

132. Szewczyk MM, Pande J, Akolkar G, Grover AK. (2010) Caloxin 1b3: A novel plasma membrane $\mathrm{Ca}^{2+}$-pump isoform 1 selective inhibitor that increases cytosolic $\mathrm{Ca}^{2+}$ in endothelial cells. Cell Calcium, 48, 352-357.

133. Mohamed TMA, Zakeri SA, Baudoin F, Wolf M, Oceandy D, Cartwright EJ, Gul S, Neyses L. (2013) Optimisation and validation of a high throughput screening compatible assay to identify inhibitors of the plasma membrane calcium ATPase pump - a novel therapeutic target for contraception and malaria. J. Pharm. Pharmaceut. Sci., in press (Vol. 16, issue 2).

134. Holton ML, Wang W, Emerson M, Neyses L, Armesilla AL. (2010) Plasma membrane calcium ATPase proteins as novel regulators of signal transduction pathways. World J. Biol. Chem., 1, 201-208.

135. Juranic N, Atanasova E, Filoteo AG, Macura S, Prendergast FG, Penniston JT, Strehler EE. (2010) Calmodulin wraps around its binding domain in the plasma membrane $\mathrm{Ca}^{2+}$ pump anchored by a novel 18-1 motif. J. Biol. Chem., 285, 4015-4024.

136. Tidow H, Poulsen LR, Andreeva A, Knudsen M, Hein KL, Wiuf C, Palmgren MG, Nissen P. (2012) A bimodular mechanism of calcium control in eukaryotes. Nature, 491, 468-472. 
137. Toyoshima C. (2009) How $\mathrm{Ca}^{2+}$-ATPase pumps ions across the sarcoplasmic reticulum membrane. Biochim. Biophys. Acta, 1793, 941-946.
138. Moeller JV, Olesen C, Winther A-ML, Nissen P. (2010) The sarcoplasmic $\mathrm{Ca}^{2+}$-ATPase: design of a perfect chemi-osmotic pump. Quart. Rev. Biophys., 43, 501-566. 